\title{
Pulpotomies with Low-Level Laser Therapy in Human Primary Teeth: A Report of Two Cases
}

\author{
Natalino Lourenço Neto, Ana Paula Fernandes, Nádia Carolina Teixeira Marques \\ Maria Aparecida Andrade Moreira Machado, Ruy Cesar Camargo Abdo, Thais Marchini Oliveira
}

\begin{abstract}
Several studies investigating the Low-Level Laser Therapy (LLLT) have shown their potential to increase healing, stimulate dentinogenesis and preserve vitality of the dental pulp. The aim of this case report is to show two clinical cases of pulpotomy with LLLT in the mandibular primary molars followed by calcium hydroxide at 6,12 and 18 months clinical and radiographic follow-up. The clinical and radiographic examination of the pulpotomized teeth and their periradicular area revealed that the treatments were successful in maintaining the teeth asymptomatic and preserving pulpal vitality. LLLT may be considered as an effective alternative for primary teeth. Although our results are encouraging, further studies and longer followup assessments are needed in order to determine the clinical indication of LLLT.
\end{abstract}

Keywords: Primary teeth, Pulpotomy, Low level laser therapy.

How to cite this article: Neto NL, Fernandes AP, Marques NCT, Machado MAAM, Abdo RCC, Oliveira TM. Pulpotomies with Low-Level Laser Therapy in Human Primary Teeth: A Report of Two Cases. Int J Laser Dent 2013;3(3):105-108.

Source of support: Nil

Conflict of interest: None declared

\section{INTRODUCTION}

Pulpotomy is the most widely accepted clinical procedure for treating primary teeth when the coronal pulp tissue is exposed by caries during caries removal or trauma. This technique consists of removing the coronal pulp and fixing the radicular pulp with a medicament. The purpose is to remove the inflamed and infected pulp, leaving the treated tooth asymptomatic until its exfoliation. ${ }^{1,2}$

Not only the correct indication of the pulpotomy technique is required for this therapy to succeed, but also the selection of an effective and biocompatible material. ${ }^{2,3}$ Different pulpal agents have been used as a pulpotomy medicament, however, none of the medicament available and recommended for pulpotomy therapy presents all the requirements of an ideal pulp capping agent. ${ }^{2,4-5}$ Currently, the formocresol, that was considered in the past a 'gold standard', in pulp therapy is not indicated due to pulpal inflammatory response, cytotoxity and mutagenic and carcinogenic potential. ${ }^{6-8}$

Recently, the use of low-level laser therapy (LLLT) has shown great promise in the treatment of the oral cavity tissues. ${ }^{9-14}$ This technology is getting space on dentistry either complementing or replacing traditional methods with a simple approach, offering a series of advantage, such as minimally invasive, highly selective and diagnostically reduces the need for postoperative medicaments. . $^{9} 10,12,15-17$

The aim of this case report is to show two clinical cases of pulpotomy using the LLLT on the pulp tissue in mandibular primary molars followed by calcium hydroxide at 6,12 and 18 months clinical and radiographic follow-up.

\section{CASE REPORTS}

A 5-year-old boy and a 6-year-old girl were referred to our institution with a request for dental care because of the presence of caries lesion. They had no systemic pathology or known allergies to latex, topical or local anesthetics. The parents or guardians of the children received detailed information concerning the procedures involved in the treatment and signed informed consent forms.

In both the cases, the children presented mandibular primary molars with deep caries, presenting no signs of radicular pulp degeneration (abscesses of associated fistulous tracts) and at radiographic exam no signs of furcation involvement, internal or external pathological root resorption, or pathological thickening of the periodontal membrane; no increased mobility; two-third or more of root length and possibility of restoration. The girl presented first and second left primary molars (Fig. 1A) and the boy a right first primary molar (Fig. 2A).

After local anesthesia with 4\% Articaine with 1:100,000 Epinephrine, caries removal were achieved with a slowspeed turbine after rubber dam isolation. The opening of the pulp chambers were carried out with high speed, round carbide bur. Complete coronal pulp tissue were removed manually with a sterile sharp spoon excavator, followed by irrigation with saline solution in order to clear off the debris. The wound surface was continuously irrigated with saline solution until bleeding ceased. Hemorrhage control was achieved by placing a dry sterile cotton pellet on the radicular pulp stumps under slight pressure for 5 minutes to homeostasis. The LLLT equipment used was the Twin Flex Evolution (MMOptics ${ }^{\odot}$, São Carlos, SP, Brazil) and was applied above the pulp stamps tissues using a special tip in the laser device and the following parameters: $660 \mathrm{~nm}$; $10 \mathrm{~mW} ; 2.5 \mathrm{~J} / \mathrm{cm}^{2}$ for 10 seconds. After that the calcium hydroxide was applied into the pulp chambers with an amalgam carrier, above this material, a layer of reinforced 

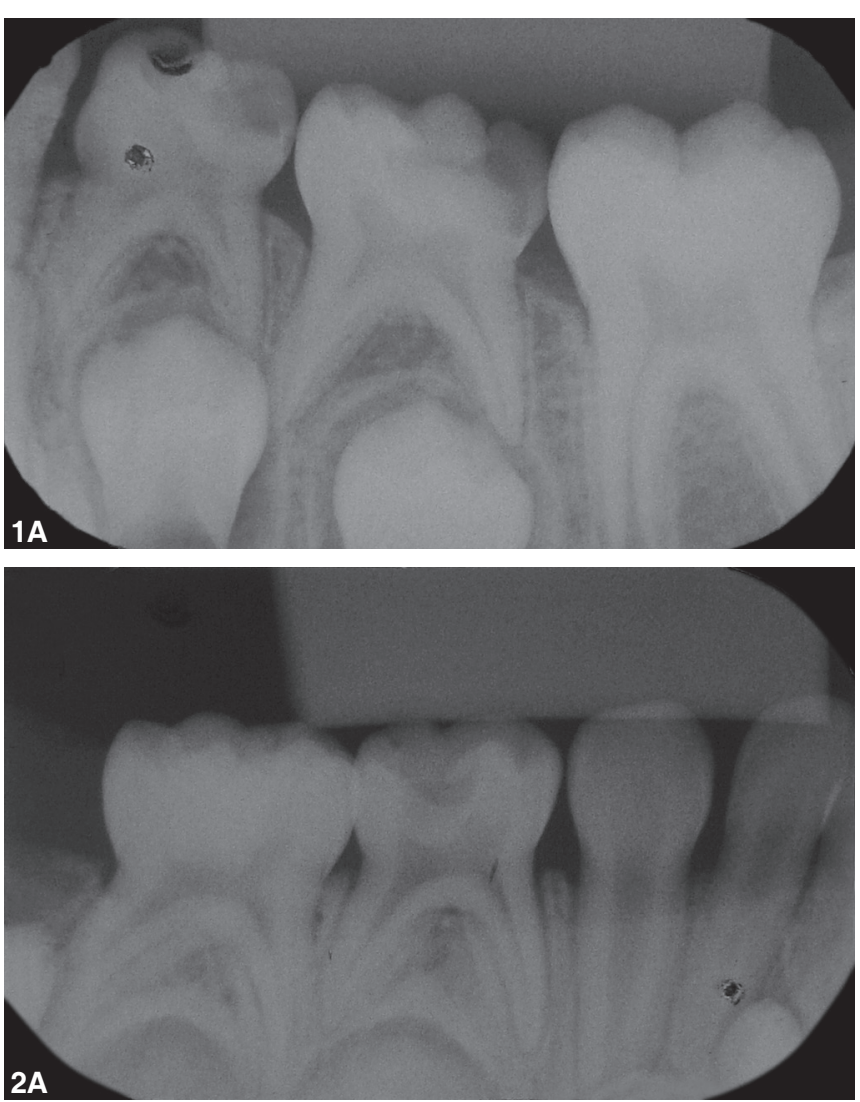

Figs 1A and 2A: Preoperative periapical radiographs of the first and second mandibular left primary molars of a 6-year-old girl and the mandibular right primary molar of a 5-year-old boy. The pulpotomy were indicated for the treatment of the primary teeth, which presented an extensive caries lesion, more than two thirds of root length, and no signs of radicular pulp degeneration, furcation involvement, internal or external pathological root resorption, or pathological thickening of the periodontal membrane

zinc oxide-eugenol (IRM ${ }^{\circledR}$, Dentisply, Petrópolis, PR, Brazil) was placed prior to restoration with resin modified glass ionomer cement (Vitremer ${ }^{\circledR}$, 3M ESPE, São Paulo, SP, Brazil). Immediate postoperative radiographs were taken.

Periodic follow-up examinations were carried out at 6 (Figs 1B and 2B), 12 (Figs 1C and 2C) and 18 months (Figs 1D and 2D) after the end of the treatment. Each checkup involved a clinical and radiographic examination of the pulpotomized teeth and their periradicular area, revealing that the treatments were successful in retaining the teeth asymptomatic. The patients will be monitored quarterly in order to follow-up the pulpotomized molars and the eruption of all permanent teeth.

\section{DISCUSSION}

Since the introduction of low-power lasers on the market, several studies investigating the application of LLLT to dental tissues have shown their potential to increase healing, stimulate dentinogenesis and preserve the dental pulp vitality. ${ }^{9,10,14}$ Histopathological studies have been
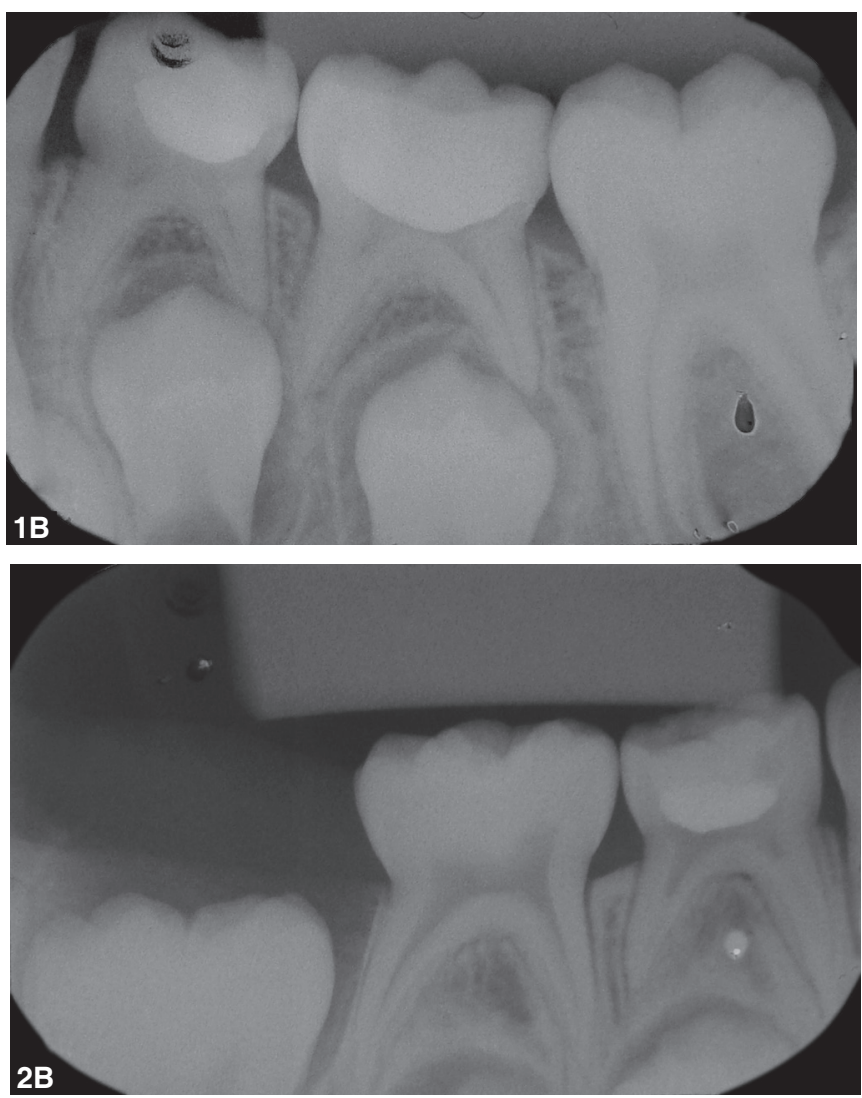

Figs 1B and 2B: Six month postoperative radiographs follow-up. The pulpotomy were considered success, and shows good quality of the surrounding tissues of the treated teeth, no signs of internal or external resorption on the teeth roots
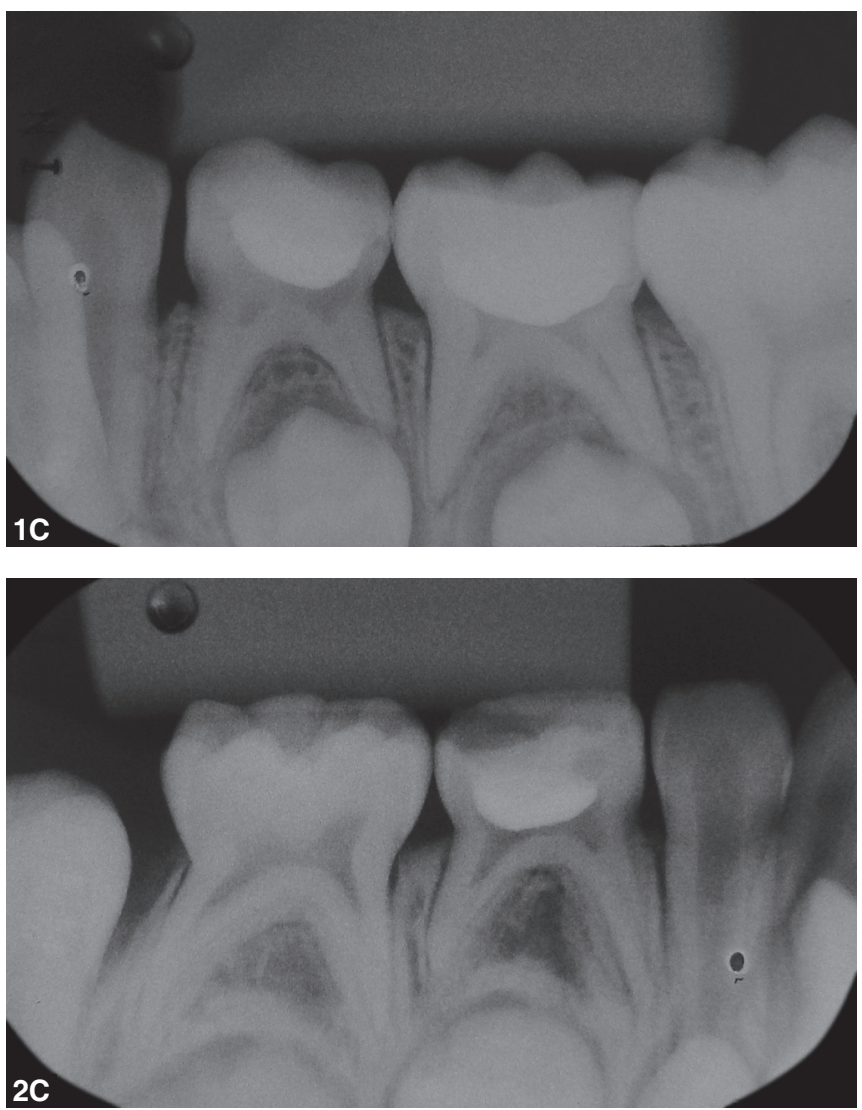

Figs 1C and 2C: Twelve-month postoperative radiographs followup. No sign of failure following pulp treatment using low-level laser therapy 

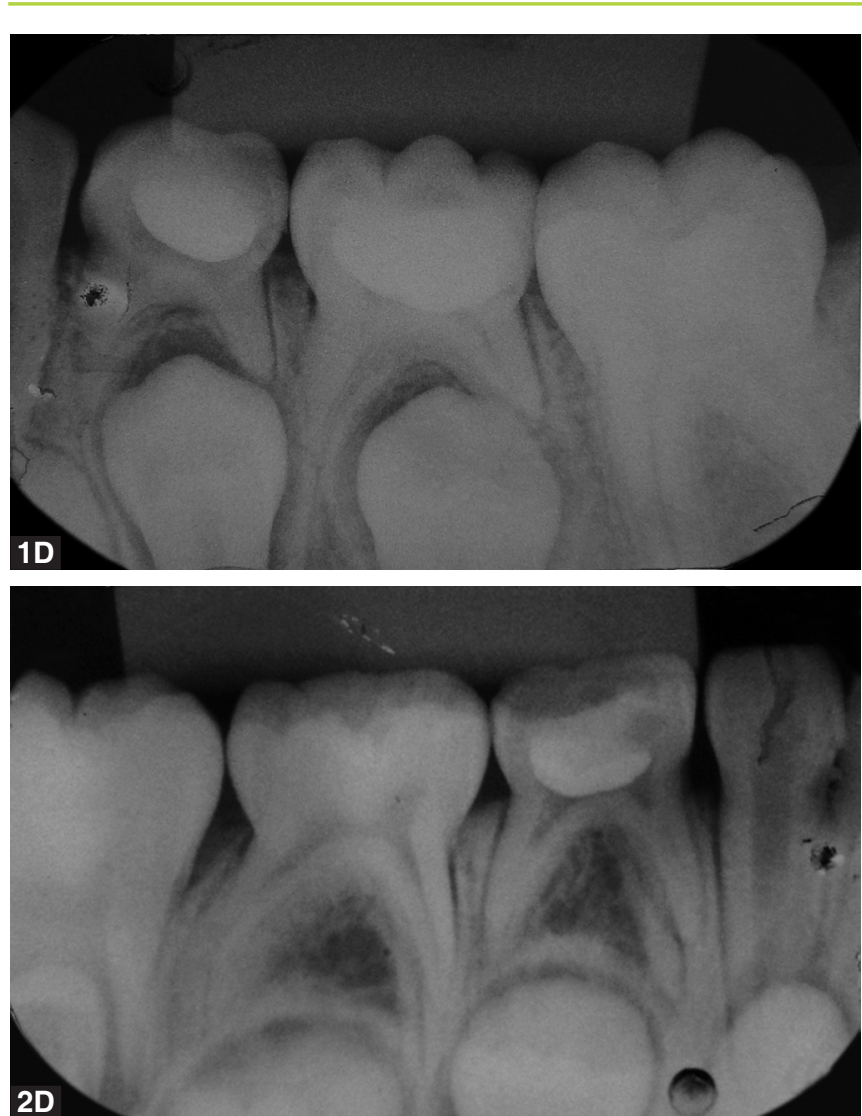

Figs 1D and 2D: Eighteen month postoperative radiographs follow-up. The pulpotomy continued to be considered success, no signs of internal or external resorption on the teeth roots and good quality of the restorations

carried out to evaluate the biomodulatory effects of LLLT in the pulp inflammatory process, reducing inflammation and accelerating tissue repair by creating a fibrous matrix and dentin bridge and increasing the production of collagenic protein. ${ }^{11}$ In the pulp, the LLLT increases the neovascularization and the formation of a regenerative tissue, and also influence in the proliferation of dental reparative cells like osteoblast and fibroblasts. ${ }^{18-21}$ In this clinical cases presented, the LLLT was the treatment of choice to use on the pulp chamber and prepare the remaining tissue for the chosen dressing material calcium hydroxide.

Calcium hydroxide has been used in pulpotomies of primary teeth with clinical and radiographic success; it was capable of forming a mineralized barrier. ${ }^{22}$ It is considered more biocompatible material for the pulp tissues, and presents antibacterial and biocompatible properties. ${ }^{23,24}$ The alkaline $\mathrm{pH}$ induced by calcium hydroxide not only neutralizes lactic acid from osteoclasts, thus preventing dissolution of the mineral components of dentin, but can also activate alkaline phosphatases, which play an important role in hard tissue formation. ${ }^{23,24}$ This pulp dressing agent has the potential to maintain the vitality of the remaining radicular pulp, with the formation of a mineralized tissue barrier in the region where the pulp was amputated. ${ }^{22-24}$
The use of lasers in surgical and clinical procedures has provided technology and higher comfort to the patients. ${ }^{25}$ The evidence demonstrated by researches s $^{9,10,12,15}$ and in this clinical case report support the use of LLLT as a complement in pulpotomy therapy in primary teeth. Our cases revealed that the LLLT may be considered as an effective alternative for primary molars pulpotomies, since the treated teeth were retained asymptomatic in the oral cavity, according to the results obtained by Golpayegani $(2010)^{9}$ and Golpayegani (2009). ${ }^{10}$ Although our results are encouraging, further studies and longer follow-up assessments are needed in order to determine the clinical indication of LLLT.

\section{REFERENCES}

1. Erdem AP, Guven Y, Balli B, Ilhan B, Sepet E, Ulukapi I, Aktoren O. Success rates of mineral trioxide aggregate, ferric sulfate, and formocresol pulpotomies: a 24-month study. Pediatr Dent 2011;33(2):165-170.

2. Fuks AB. Vital pulp therapy with new materials for primary teeth: new directions and treatment perspectives. Pediatr Dent 2008;30(3):211-219.

3. Walker LA, Sanders BJ, Jones JE, Williamson CA, Dean JA, Legan JJ, Maupome G. Current trends in pulp therapy: a survey analyzing pulpotomy techniques taught in pediatric dental residency programs. J Dent Child (Chic) 2013 Jan-Apr; $80(1): 31-35$.

4. Blanchard S, Boynton J. Current pulp therapy options for primary teeth. J Mich Dent Assoc 2010 Jan;92(1):38, 40-41.

5. Seale NS, Coll JA. Vital pulp therapy for the primary dentition. Gen Dent 2010 May-Jun;58(3):194-200.

6. Lucas Leite AC, Rosenblatt A, da Silva Calixto M, da Silva CM, Santos N. Genotoxic effect of formocresol pulp therapy of deciduous teeth. Mutat Res 2012;747(1):93-97.

7. Lewis B. The obsolescence of formocresol. Br Dent J 2009;207(11):525-528.

8. Lewis B. The Obsolescence of formocresol. CDA J 2010;38(2): 102-107.

9. Golpayegani MV, Ansari G, Tadayon N. Clinical and radiographic success of lowlevel laser therapy (LLLT) on primary molars pulpotomy. Res J Biol Sci 2010;5:51-55.

10. Golpayegani MV, Ansari G, Tadayon N, Shams Sh, Mir M. Low-level laser therapy for pulpotomy treatment of primary molars. J Dent 2009;6(4):168-174.

11. Ferreira ANS, Silveira L, Genovese WJ, Araújo VC, Frigo L, Mesquita RA, Guedes E. Effect of GaAIAs laser on reactional dentinogenesis induction in human teeth. Photomed Laser Surg 2006;24(3):358-365.

12. Huth KC, Hajek-Al-Khatar N, Wolf P, Hickel INR, Paschos E. Long-term effectiveness of four pulpotomy techniques: 3-year randomized controlled trial. Clin Oral Investig 2012;16(4): 1243-1250.

13. Kotlow L. Lasers and soft tissue treatments for the pediatric dental patient. Alpha Omegan 2008;101(3):140-151.

14. Liu JF. Effects of Nd:YAG laser pulpotomy on human primary molars. J Endod 2006;32:404-407.

15. Odabas ME, Bodur H, Barus E. Clinical, radiographic, and histopathologic evaluation of Nd:YAG laser pulpotomy on human primary teeth. J Endod 2007;33:415-421. 
16. Toomarian L, Fekrazad R, Sharifi D, Baghaei M, Rahimi $\mathrm{H}$, Eslami B. Histopathological evaluation of pulpotomy with Er,Cr:YSGG laser vs formocresol. Lasers Med Sci 2008;23(4):443-450.

17. Caprioglio C, Olivi G, Genovese MD. Lasers in dental traumatology and low laser therapy. Eur Arc Paed Dent 2011; 12(2):79-95.

18. Almeida-Lopes L, Rigau J, Zângaro RA, Guidugli-Neto J, Jaeger MM. Comparison of the low level laser therapy effects on cultured human gingival fibroblasts proliferation using different irradiance and same fluence. Lasers Surg Med 2001;29(2):179-184.

19. Damante CA, De Micheli G, Miyagi SP, Feist IS, Marques MM. Effect of laser phototherapy on the release of fibroblast growth factors by human gingival fibroblasts. Lasers Med Sci 2009;24(6):885-891.

20. Eduardo Fde P, Bueno DF, de Freitas PM, Marques MM, PassosBueno MR, Eduardo Cde P, Zatz M. Stem cell proliferation under low intensity laser irradiation: a preliminary study. Lasers Surg Med 2008;40(6):433-438.

21. Kimura Y, Yonaga K, Yokoyama K, Watanabe H, Wang X, Matsumoto K. Histopathological changes in dental pulp irradiated by Er:YAG laser: a preliminary report on laser pulpotomy. J Clin Laser Med Surg 2003;21(6):345-350.

22. Oliveira TM, Moretti ABS, Sakai VT, Lourenço Neto N, Machado MAAM, Abdo RCC. Clinical, radiographic and histologic analysis of the effects of pulp capping materials used in pulpotomies of human primary teeth. European Archives of Paediatric Dentistry 2013;14(2):65-71.

23. Alaçam A, Odabaş ME, Tüzüner T, Sillelioğlu H, Baygin. Clinical and radiographic outcomes of calcium hydroxide and formocresol pulpotomies performed by dental students. Oral Surg Oral Med Oral Pathol Oral Radiol Endod 2009; 108:127-133.

24. Moretti AB, Sakai VT, Oliveira TM, Fornetti AP, Santos CF, Machado MA, Abdo RC. The effectiveness of mineral trioxide aggregate, calcium hydroxide and formocresol for pulpotomias in primary teeth. Int Endod J 2008;41:547-555.

25. Cannon M, Wagner C, Thobaben JZ, Jurado R, Solt D. Early response of mechanically exposed dental pulps of swine to antibacterial-hemostatic agents or diode laser irradiation. J Clin Pediatr Dent 2011;35(3):271-276.

\section{ABOUT THE AUTHORS}

\section{Natalino Lourenço Neto}

Postdoctoral Student, Department of Pediatric Dentistry, Orthodontics and Public Health, University of São Paulo, Bauru School of Dentistry Brazil

\section{Ana Paula Fernandes}

PhD Student, Department of Pediatric Dentistry, Orthodontics and Public Health, Bauru School of Dentistry, University of São Paulo Brazil

\section{Nádia Carolina Teixeira Marques}

PhD Student, Department of Pediatric Dentistry, Orthodontics and Public Health, Bauru School of Dentistry, University of São Paulo Brazil

\section{Maria Aparecida Andrade Moreira Machado}

Full Professor, Department of Pediatric Dentistry, Orthodontics and Public Health, Bauru School of Dentistry, University of São Paulo Brazil

\section{Ruy Cesar Camargo Abdo}

Full Professor, Department of Pediatric Dentistry, Orthodontics and Public Health, Bauru School of Dentistry, University of São Paulo Brazil

\section{Thais Marchini Oliveira}

Associate Professor, Department of Pediatric Dentistry, Orthodontics and Public Health, Bauru School of Dentistry, University of São Paulo Brazil

Correspondence Address: Thais Marchini Oliveira, Bauru School of Dentistry, University of São Paulo, Alameda Dr Octávio Pinheiro Brisolla, 9-75, Bauru, São Paulo, 17012-901, Brazil, Phone: +551432358224, e-mail: marchini@usp.br 